\title{
Tourist loyalty and destination brand image perception: the case of Sunny beach resort, Bulgaria
}

\author{
Lina Anastassova ${ }^{1 *}$
}

\author{
Received: 04/04/2011 Accepted: 27/07/2011
}

\footnotetext{
${ }^{1}$ Head of Marketing Programme, Center for Business Studies, Burgas Free University; 62 San Stefano St., Burgas 8000, Bulgaria; email: anastassova@bfu.bg

${ }^{*}$ Corresponding author
}

\begin{abstract}
Research related to important marketing aspects of international tourism has increased significantly. The analysis and exploration of the concept of loyalty is gaining a significant attention in the tourism research during the last two decades. The main objectives of this research paper are: first to explore the tourist population structure of the Bulgarian Sunny Beach resort depending on the loyalty level of the tourists to Sunny Beach brand and to make an attempt for extracting a typology of the tourist segments. The second task of the research paper is to determine the brand image perception by the tourists with different level of loyalty and to identify the key attributes of the tourism product which distinguish the image of Sunny beach brand. The study analysis and conclusions are based on two probability samples- in seasons 2009 and 2010- stratified samples according to the variable "country of origin". The study reveals differences in the image perceptions of loyal and disloyal tourists and points out that better understanding of the image perception by the loyal tourists can help the marketers to improve the destination branding strategy.
\end{abstract}

(C) 2011 International University College. All rights reserved

Keywords: tourist loyalty, destination brand, image perception

Citation: Anastassova, L. (2011) Tourist loyalty and destination brand image perception: the case of Sunny beach resort, Bulgaria. European Journal of Tourism Research 4(2), pp. 191-204

\section{Introduction}

Tourism is a key industry in the Bulgarian economy and it contributes according to different official and unofficial statistical sources by $13-14 \%$ to the Gross Domestic Product (GDP) (http://www.nsi.bg; http://www.investbulgaria. com; http://www.wttc.org). The revenues in the tourism industry depend directly from the tourist flow incoming to the country as the domestic tourism contribution is low: the Bulgarian tourists spend 10 times more abroad than in
Bulgaria

(http://www.dnevnik.bg/pazari/). Having in mind the enormous global competition on the tourism market due to the new emerging tourist destinations the issue of international tourist loyalty becomes more and more important in growing number of publications (Reichheld, 2001; De Wulf, Odekerken-Schroder \& Jaccobucci, 2001, Niininen \& Riley , 2003; Groeppel-Klein, Koenigstorfer \& Terlutter, 2008; Tsu \& Cai, 2009; Yuksel, Yuksel \& Bilim, Y., 2010). 
Correspondingly, research related to important marketing aspects of international tourism like destination brand perception by different types of tourists, key attributes of the tourism product related to the brand image and other has increased significantly (Blain, Levy \& Ritchie, 2005; Iwasaki and Havitz ,2004; Tsu \& Cai, 2009).

A lot of research, including this of Baker and Crompton, provides evidence that the strong link between loyalty and profitability is a reality in the tourism industry (Baker \& Crompton, 2000). This fact determines the significance of the tourist loyalty as a marketing task for the destinations and not on last place because there may be a relationship between the loyal tourists' behaviour and the destination brand image. Like brand loyalty is generally considered desirable from a strategic marketing perspective, so is destination brand loyalty the focus of the strategic destination marketing (Christopher, Payne \& Ballantyne, 2004). The analysis and exploration of the concept of loyalty gained a growing attention in the tourism research and the study of customer loyalty has been determined as one of the major driving forces in the new marketing era (Brodie, et al., 1997). Research reveals that understanding which factors increase tourist loyalty is valuable information for tourism marketers and managers (Gummesson, 1987; Buttle, 1996; Groenroos, 1999; Flavian et al., 2001 2001, Tsu \& Cai, 2009; Yuksel, Yuksel \& Bilim, Y., 2010). More recent research and publications develop the concept of relationship marketing which is considered as a new marketing paradigm with stressing on loyalty and consumer retention instead of new customer acquisition (Christopher, Payne \& Ballantyne, 2004; Reichheld, 2001; Sheth and Parvatiyar,2000; Uncles, Dowling \& Hammond, 2003; Blattberg, Getz \&Thomas, 2009; Huber \& O'Gorman, 2010). The loyal tourists can serve as informal public opinion leaders for every destination- no matter recreational, cultural, ecological or rural destination and for this reason their perception of the destination brand image is very important for the destination marketers in order to manage it successfully.

The main objectives of the research paper are:
- $\quad$ to explore the tourist population structure of the resort depending on the loyalty level of the tourists to Sunny Beach brand in order to extract a typology of the tourist segments based on their loyalty;

- to explore relationship between the general tourist satisfaction by the destination and the loyalty level;

- to investigate the effect of satisfaction with the destination product attributes on their loyalty and the intention for next holiday in the destination;

- to determine the brand image perception by the tourists with different level of loyalty and to identify the key attributes of the tourism product which distinguish the image of Sunny beach brand from other Black Sea destinations.

\section{Destination brand image and tourist loyalty}

A powerful brand is a key asset in a company's global market strategy (Khermouch, Holmes and Ihlwan, 2001; Kotler, 2010). Branding is an intangible asset that can increase a firm's value (Deagon, 2002; Wheeler, 2011) and enables a firm to communicate an identity and image about a product or service (Wheeler, 2009; Clifton, 2009) to generate a level of consumer acceptance. Although the topic of product branding first appeared in the marketing theory nearly 50 years ago, research on destination branding has emerged first in the second half of the 1990s, with the first journal article published in 1998 (Pritchard and Morgan, 1998).

Destination branding is defined as "selecting a consistent element mix to identify and distinguish [a destination] through positive image-building" (Cai 2002; Govers and Go, 2009) and has been considered synonymous with (re) positioning (Gilmore, 2002), imagebuilding (Greenberg, 2008; Lewis-Cameron \& Roberts, 2010) and image-reconstruction of a destination (Hall, 2002). Ritchie and Ritchie (1998) describe tourism destination brand as something- name, symbol, logo etc. that both identifies and differentiates the destination; furthermore, it conveys the promise of a memorable travel experience that is uniquely associated with the destination; it also serves to considerate and reinforce the recollection of pleasurable memories of destination 
experience. A growing number of researchers and academics agree that in today's competitive tourism market, destination branding is an effective tactic for building successful tourism images and programs (Morgan \& Pritchard, 1999; Kim, Mc Kercher \& Lee, 2009; Marzano \& Scott, 2009; LewisCameron \& Roberts, 2010). This is so because tourists depend on their knowledge of the destination to evaluate whether the brand could satisfy their travel needs. Reasonably the topic of destination image and branding enjoys a growing scientific attention (Gartner, 1989,1993; Gallanza, Gil \& Calderon, 2002; Nadeau, Heslop, O'Reilly \& Luk, 2008; White, 2004; Yuksel \& Akgul, 2007).

According to Morgan, Pritchard and Pride (2004) when it comes to branding, perhaps the most difficult task facing any destination is the quest for true differentiation. Destination managers have been studying their potential customers to find out what exactly they look for from a holiday or short break (Pride, 2004; Wheeler, 2009). But not less important for the destination marketers and managers is to identify what the loyal tourists think about their favourite destination eg. what is the destination image as they provide word-by-mouth advertising. Nowadays the information from trusted source- friends, relatives, colleagues as well as shared opinion from other people in social media is very valuable for every consumer including tourism product consumer. A number of researchers have argued that word-of-mouth is the most effective source of information for consumers (Christopher, Payne \& Ballantyne, 2004). It is even sometimes easier for a tourist to respond honestly to a question about whether he or she would recommend the product or service to others than to a question for intention to repurchase the product or service. And this process is now facilitated through the social media networking which leads to a shift in the destination marketing in a sense: the weight on brand identity creation is shifting to brand image as perceived by the public community/consumers. The loyal tourists can serve as informal public opinion leaders for every destination - no matter recreational, cultural, ecological or rural destination (Anastassova, 2004). A destination brand like the brand of material products can not last long without proper managementbrand image management, marketing communications management etc. (Kapferer, 1992; Schmitt and Simonson, 1997, Pike, 2004). The process is even more complicated because of the diversity of the destination product attributes and the difficulties in the coordination between the activities of the different stakeholders of the destination. The destination brand needs periodic refreshment through change of its logo, slogan and /or the association set in order for potential tourists to see more and different reasons to (re)visit it (Ivanov, Illum \& Liang, 2010). In this context it is extremely important that the destination marketers know in detail the destination perception of the loyal and other tourists of this destination, so they can take decisions either for strengthening the brand image or repositioning the destination brand.

According to Crompton (1979) "an image may be defined as the sum of beliefs ideas and impressions that a person has of a destination". The image of a destination has become a very important issue in the marketing research in the tourism industry, since many countries use promotion and global marketing to support their image, and to compete with other destinations (Lin \& Huang, 2009). MacKay and Fesenmaier (1997) specified that destination image is the visitor's total impression which is formed as a result of the evaluation of various destination elements and attributes. This definition emphasizes the role of actual experience at the destination in forming the destination image.

Different researchers contributed to the understanding of destination image during the last 30 years. Ecthner \& Ritchie (1993) proposed framework for destination image measurement and Blain, Levy and Ritchie (2005) extended the understanding of the image construct by including its relation to an assessment of destination brand practices.

Destination image affects according to various authors prospective markets through the construction of place awareness, availability and evaluation; the image secures tourists' destination choice (Um and Crompton, 1990; 
Tourist loyalty and destination brand image perception: the case of Sunny beach resort, Bulgaria.

Chon, 1991; Baloglu and McCleary, 1999; Day, Skidmore \& Koller, 2002; Govers \& Go, 2009). It is a crucial component of tourists' decisionmaking process and according to many destination marketing researchers the management of destination image needs to be strategically directed (Barich and Kotler, 1991; Howard, 1998; Laws, Scott \& Parfitt, 2002; Pike, 2004). Similar to product and corporate image management, destination image management has many advantages, including being able to quickly identify shifts in destination perceptions and develop action plans, identify areas of concern and focus action to develop these components, identify areas of success and focus action to promote these components and assess whether image management action is working (Barich \& Kotler, 1991). Additionally, the destination needs to provide a realistic image to satisfy visitors' needs, specifically to create a positive evaluation and choice (Moutinho, 1987; Um \& Crompton, 1990; Joppe, Martin \& Waalen 2001; Akama \& Kieti, 2003). The positive perceived brand image can help the consumers to support the destination and to make further recommendations for it. For the purposes of this study the phenomenon of "destination image" is defined by 2 elements: the perceptions of the product characteristics by the tourist market and the profile of the product consumers.

\section{Tourist loyalty levels and hypotheses}

According to Oliver (1999b) loyalty is "... a deeply held commitment to rebuy or repatronize a preferred product/service consistently in the future, thereby causing repetitive same-brand or same-brand set purchasing, despite situational influences and marketing efforts having the potential to cause switching behaviors. He suggests that ultimate customer loyalty is a function of perceived product superiority, personal fortitude, social bonding and their synergistic effects. According to Konecnik and Gartner (2007) loyalty is from consumers' point of view one of four dimensions together with awareness, image and quality of destination brand equity defined as "the differential effect of brand knowledge on consumer response" (Kohli and Leuthesser,
2001) and this determines the importance of this phenomenon.

In order to explore the tourist loyalty towards Sunny Beach Resort, the study needs conceptualization of tourist loyalty and selection of empirical variables for term operationalization. For the purposes of the research a set of 4 empirical indicators was used which according to the author cover 3 main characteristics of the phenomenon; cognitive, affective and behavioral aspects of the tourist loyalty (Oliver, 1997):

number of visits in the destination for the last 5 years;

number of recommendations done for the resort;

- intention for future visits in the destination;

- attachment (affiliation) to the destination because a brand possesses a strong emotional charge that attracts customers (Cleverton, 2006).

Tourist loyalty can be affiliated even with the destination brand name which can have positive connotations that affect tourists' attitudes which may contribute to their travel motivation and add to satisfaction (Clark, 2009: 111). A lot of studies in the marketing literature explore the nature of the loyalty and its determining factors. According to Bitner (1990), Dick \&Basu (1994) and Oliver (1999), in all situations the satisfaction from products and services affect consumer loyalty. Baker and Crompton (2000) define satisfaction as the tourist's emotional state after experiencing the trip. According to Fornell (1992) satisfaction assessment is a must because it can help managers to improve services and to compare organisations and destinations in terms of performance (Kotler,1994). For the purposes of this research the tourist satisfaction with different destination product attributes was assessed by 4 -point rating scales.

On the basis of the research of Oliver (1999b), Bitner (1990), Dick \& Basu (1994) and Anastassova (2002) a group of 5 hypotheses was formulated for the purposes of this research: 
H1: The higher overall satisfaction with the holiday has positive impact on the behavioral loyalty which means that higher overall satisfaction with the holiday leads to repeat visits at the destination;

H2: The tourists with higher destination brand loyalty (combination of number of visits in the destination and number of recommendations done) are expected to have clearer and more focused image perception than the tourist with lower destination loyalty which are expected to show unclear, disperse and not very positive destination image perception;

H3: The tourists who are more likely inclined to recognize the destination as "my destination" are expected to have stronger confidence that they will come again for holiday in this destination;

H4: The tourists with higher cognitive loyalty eg. more recommendations done are more likely to identify themselves with the destination than the tourists with behavioral loyalty (number of visits in the destination);

H5: The different satisfaction level with the single attributes of the destination tourism product has a different impact on the intention for future visits in the destination: the attributes with higher satisfaction level have a stronger impact on the tourists' decision for a next destination visit.

\section{Methodology}

For the purposes of the survey the sample model chosen was stratified proportionate sample according to the variable "country of origin" based on incoming tourists forecast data for Sunny Beach. The assumption for this sample model is that the sample reproduces the population structure by the stratifying variable (Baker, 1991). There was random choice of the tourists from different countries in 14 hotels in Sunny beach resort in the last 2 summer seasons- 2009 and 2010 . The sample fulfilled is 580 tourists in season 2010 and 290 tourists in season 2009 and they from different countries according to the forecast data for the season- mainly from UK, Scandinavian countries, Russia and Germany. Although the differences upon countries of the fulfilled sample with the planned sample are statistically non-significant (differences in the range up to 0.6 ) the survey information can not be considered as representative for the tourist population in Sunny Beach resort for both seasons but it gives a good basis for useful conclusions.

As far as the measurement scales concerns the survey used mainly 4-point rating scales which are usually implemented as a measurement instrument in similar survey research and which are considered as

Table 1. Conceptual terms, empirical variables and scales

\begin{tabular}{|c|c|c|c|}
\hline $\begin{array}{c}\text { Conceptual } \\
\text { Term }\end{array}$ & $\begin{array}{c}\text { Monitored } \\
\text { empirical variables }\end{array}$ & Questions & Scale \\
\hline \multirow[t]{3}{*}{$\begin{array}{l}\text { Loyalty to } \\
\text { Tourist } \\
\text { Destination }\end{array}$} & Number of visits & $\begin{array}{l}\text { How many times did } \\
\text { you visit the destination } \\
\text { in the } 7 \text {-year period? }\end{array}$ & $\begin{array}{l}\text { First time } \\
\text { Second time } \\
\text { Third time } \\
\text { More than } 3 \text { times }\end{array}$ \\
\hline & $\begin{array}{l}\text { Number of } \\
\text { recommendations done }\end{array}$ & $\begin{array}{l}\text { To how many people } \\
\text { did you make } \\
\text { recommendations? }\end{array}$ & $\begin{array}{l}\text { Up to } 5 \text { people } \\
6-10 \text { people } \\
11-15 \text { people } \\
\text { Over } 15 \text { people }\end{array}$ \\
\hline & $\begin{array}{l}\text { Intentions for future } \\
\text { destination visits }\end{array}$ & $\begin{array}{l}\text { Do you intend to visit } \\
\text { the destination again? }\end{array}$ & $\begin{array}{l}\text { Yes, definitely } \\
\text { Yes, almost sure } \\
\text { To a great extent yes } \\
\text { Probably not }\end{array}$ \\
\hline $\begin{array}{l}\text { Emotional } \\
\text { attachment/ } \\
\text { Affiliation } \\
\text { to the } \\
\text { destination }\end{array}$ & $\begin{array}{l}\text { Recognition of the } \\
\text { destination as "my } \\
\text { destination" }\end{array}$ & $\begin{array}{l}\text { Can you say for Sunny } \\
\text { beach resort "This is my } \\
\text { destination"? }\end{array}$ & $\begin{array}{l}\text { Yes, definitely } \\
\text { Yes, almost sure } \\
\text { To a great extent yes } \\
\text { Probably not }\end{array}$ \\
\hline
\end{tabular}


Tourist loyalty and destination brand image perception: the case of Sunny beach resort, Bulgaria.

appropriate when satisfaction and loyalty explored are (Aaker, Furnier, Brasel, 2004; Oliver, 1980; Uhrich, 2008).

The term "loyalty towards tourist destination" has been operationalized in this study by the following empirical indicators, survey questions and scales:

For identification of the different loyalty levels of the foreign tourists in Sunny beach the cluster analysis was implemented which is a preferred mode for analyzing a large data base. Cluster analysis is a kind of statistical techniques for discovering structure (groupings) within a complex set of data. In tourism research cluster analysis is often used to identify market segments in order to improve the effectiveness of market efforts (Mazanec,1984; Keng and Cheng, 1999; Arimond and Elfessi, 2001; Satish Chandra and D. Menezes,2001; Bloom, 2004; Michael, 2007) or to identify clusters based on resident attitudes (Inbakaran \& Jackson, 2006). These segments maybe based on a variety of variables including demographic characteristics of the tourists (such as age, income, gender and location) and trip characteristics (such as trip length, purpose, group size etc.) (Jafari, 2000).

The cluster analysis was implemented in this study by using three indicators: number of visits, number of recommendations to other potential tourists and intention for future visits. As cluster analysis can be used to identify internally homogenous tourist clusters, the method may be implemented to develop a typology of tourist segments and on this basis achieve a better understanding of the structure of larger tourist population depending on the destination brand loyalty of the tourists. As far as the analysis of the relationship between the level of satisfaction and the tourist loyalty level concerns, the methods of bivariate correlation analysis and the multidimensional regression analysis were used. The data are processed through the statistical package SPSS-version 16.0 .

For identification of the differences in the clusters concerning the perception of the destination image two different methods were implemented- one quantitative and one qualitative method. First a list of variables was provided to the respondents and they had to evaluate the matching of every single attribute to the destination image which reflects their destination image perception. The list of following variables were adopted in the survey questionnaire: Beautiful beaches and landscape, Excellent accommodation facilities, Variety of dining facilities, Safety and Security, Cultural heritage, Entertainment opportunities, Services quality and Shopping variety. The respondents had to state the extent of their agreement to these visual attributes on a 5point scale. Despite of the limitations of the predetermined list of attributes this approach makes possible the direct comparisons of two separate samples' data.

The other method was from the group of the qualitative methods namely "the projective techniques" and especially a kind of association test. Projective techniques may be classified as a structured-indirect way of investigating the whys of situations (Webb,1992, p.125). They are not used to measure quantitative data but to uncover attitudes, feelings, beliefs and motivations which are qualitative indicators. In order to fulfil the planed research task a single question about associations related to the destination brand name was provided to 50 loyal and to 50 other tourists who were not included in the stratified sample which means that they are not influenced by the questions in the survey questionnaire. The question to be answered was: Which are the key words (up to 6) which come first to your mind when you hear the destination brand name "Sunny Beach". Like in many other surveys, both methods were used simultaneously, complementing each other.

\section{Results and discussion}

\section{Cluster analysis}

The cluster analysis based on three criteria pointed above determined 4 main clusters in the sample: $1^{\text {st }}$ cluster includes tourists with high loyalty level: $33,9 \%$ in 2009 and $37,3 \%$ in 2010 , they have been more than 3 times in the destination and have done more than 15 recommendations for the destination in personal contact with potential tourists (not in 
social media). For these tourists it is sure or almost sure that they will visit the destination again. $2^{\text {nd }}$ cluster includes tourists with moderate loyalty level: $20,3 \%$ in 2009 and $22,4 \%$ in 2010 , they have been 3 times in the destination, have done in average between 10 and 15 recommendations to potential tourists and the majority of them are almost sure that they will come again for holiday to the destination. $3^{\text {rd }}$ cluster- tourists with potential of development: $28,2 \%$ in 2009 and $27,5 \%$ in 2010, they are for second time in the destination and have done 5-9 recommendations personally to other tourists. $4^{\text {th }}$ cluster: the beginners who are for first time in the destination- $13,6 \%$ in 2009 and $12.8 \%$ in 2010. In fact clusters 3 and 4 are not object of this research study and analysis as they do not fit to the concept of loyalty towards the destination.

The socio-demographic profile of the loyal tourists in first and second clusters are to some extent similar but there are some differences in the social status and the age group: the tourists with high loyalty to destination in 2009 are mostly in the age group 40-49 years, married or living with a partner and on middle social level. The typical tourist with moderate loyalty in 2009 is younger - in the age group 30-39, the majority of these tourists are with an average social status and about $15 \%$ of them belong to the level above the middle.
The survey data from season 2010 reveal that the typical tourists with high loyalty are with a minimal difference younger in comparison to 2009 and the other characteristics are nearly the same like in 2009. The tourists with moderate loyalty in season 2010 are with similar characteristics like in 2009 as well: the majority of them belong to age group 30-39 years and are married or living with a partner but there is an increase in the group of these tourists. Concerning the social status nearly $75 \%$ of them are on a middle social level including lower middle level. Generally the differences in the characteristics of the loyal tourists in both seasons are insignificant.

\section{Destination image perception}

According to data analysis there are not significant differences in the destination image perception between the four clusters with different loyalty level. Generally the first cluster differs from the other clusters with the highest means upon 3 destination attributes: beaches and landscape (mean=3.77 in 2009 and 3.87 in 2010), accommodation facilities (mean $=3.61$ in 2009 and 3.59 in 2010) and entertainment variety (mean=3.19 in 2009 and 3,30 in 2010) (see Table 2). The tourists from the second cluster have better perception on first place of 'beaches and landscape' (mean=3.56 in 2009 and 3.49 in 2010), safety and security (mean=3.14 in 2009 and 3,08 in 2010) and accommodation facilities (mean=3.22 in 2009 and 3.30 in 2010). Tourists from this cluster

Table 2. Differences in clusters depending on destination attributes perception

\begin{tabular}{lcccccccc}
\hline \multicolumn{1}{c}{ Destination image attributes } & \multicolumn{2}{c}{$\begin{array}{c}\text { Cluster 1 } \\
\text { (mean) }\end{array}$} & \multicolumn{2}{c}{$\begin{array}{c}\text { Cluster 2 } \\
\text { (mean) }\end{array}$} & \multicolumn{2}{c}{$\begin{array}{c}\text { Cluster 3 } \\
\text { (mean) }\end{array}$} & $\begin{array}{c}\text { Cluster 4 } \\
\text { (mean) }\end{array}$ \\
\cline { 2 - 9 } & $\mathbf{2 0 0 9}$ & $\mathbf{2 0 1 0}$ & $\mathbf{2 0 0 9}$ & $\mathbf{2 0 1 0}$ & $\mathbf{2 0 0 9}$ & $\mathbf{2 0 1 0}$ & $\mathbf{2 0 0 9}$ & $\mathbf{2 0 1 0}$ \\
\hline $\begin{array}{l}\text { Clean and beautiful beaches and } \\
\text { landscape }\end{array}$ & 3.77 & 3.87 & 3.56 & 3.49 & 2.61 & 2.51 & 2.78 & 2.60 \\
Excellent accommodation facilities & 3.61 & 3.59 & 3.22 & 3.31 & 2.39 & 2.28 & 2.19 & 2.02 \\
Variety of eating facilities & 2.66 & 2.70 & 2.13 & 2.20 & 2.09 & 2.15 & 1.98 & 2.10 \\
Safety and security of tourists & 3.07 & 3.21 & 3.14 & 3.23 & 1.82 & 2.02 & 2.43 & 2.28 \\
Heritage and sightseeing variety & 2.72 & 2.86 & 2.38 & 2.46 & 2.11 & 2.08 & 1.97 & 2.12 \\
Entertainment variety & 3.19 & 3.30 & 2.78 & 2.91 & 1.99 & 2.08 & 2.08 & 2.19 \\
Services quality & 2.98 & 3.05 & 2.60 & 2.71 & 1.96 & 2.12 & 1.87 & 1.99 \\
Shopping variety & 2.32 & 2.22 & 2.41 & 2.30 & 2.07 & 1.98 & 1.97 & 2.02 \\
\hline
\end{tabular}


perceive Sunny beach resort as more save and secure than the tourists from the first cluster. This is a good sign for the Sunny Beach destination as previous research by the author with foreign tourists in the same resort and with representatives of tour-operators and tour agencies points out that safety and security of tourists becomes an important value when choosing a holiday destination (Anastassova, 2002, 2004).

To test the basic assumption in $\mathrm{H} 1$ the $\mathrm{x} 2$ method was used by level of significance $\alpha=0.05$. The results reveal that the relation between both variables is not accidental (occasional) and the correlation is moderate by power $(r=0.34)$ which means that the tourists with higher overall satisfaction are those with bigger number of visits at the destination. This can mean that the loyal tourists are more tolerant to the shortages in the service performance pointed out in the open-ended questions and to the destinations weaknesses generally. In fact this statement drawn by the survey results confirms the conclusions from other study in Sunny beach resort in 2002 where the overall satisfaction with the holiday of the loyal tourists is again higher than the satisfaction level of the tourists with only one visit (Anastassova, 2002).

Concerning the second research hypothesis the "association test" which belongs to the projective techniques was provided to 50 tourists with 3 and more holiday visits (loyal tourists) and to 50 tourists with first or second holiday at the destination which were not included in the stratified sample. The content analysis of the "association test" pointed out that the tourists with higher destination loyalty describe the image of the destination more often with descriptions like: destination with nice and clean beaches and landscape; destination with beautiful sea and beaches; good sandy beaches and entertainments choice, clean sandy beaches and entertainment variety; nice beaches and climate- as seen very similar descriptions. Nearly $70 \%$ of the loyal tourists use this kind of descriptions for Sunny beach resort. The conclusion is that the loyal tourists see as main features of the image the beautiful sandy beaches and the entertainment variety. Another empirical finding that deserves attention is the fact that nearly half of the loyal tourists- $46 \%$ add to the image perception a description like "a place of nice memories" or a place of "unforgettable experience" but both descriptions are related to positive feelings. As marketers try to expand the association set for a destination brand (the associations that people hold about a destination) (Ivanov, Illum \& Liang, 2010: 341). Sunny Beach destination marketers can use the key descriptions and associations of the tourists in its branding strategy. As said before loyalty can be affiliated even with the destination name and the study validated this assumption because more than $2 / 3$ of the loyal tourists use a kind of description of the destination image related to the word "beach"- beautiful, sandy, nice, clean etc. and this reveals that the core of the destination image is the attribute "beach".

The "beginners" and those who are at the destination for second time find it difficult to describe the destination, the content analysis points out that their descriptions are unclear and disperse- with no focus and not very positive- nearly $3 / 4$ of them. Some of their negative comments concern poor service quality. Tourism destination brand image generally refers to a compilation of beliefs and impressions based on information processing from various sources over time (Crompton, 1979; Yuksel \& Akgul, 2007) and the perception about a place as reflected by associations held in a tourists' memory (Cai, 2002). As perception of place is highly individual and subjective, marketers are interested not in the individual' perceptions of a destination but predominant perceptions actual and potential tourists hold about a destination and the links between these perceptions (Ivanov, Illum \& Liang, 2010: 340).

To test the assumption in the third hypothesis the $\mathrm{X} 2$-method was applied by level of significance $\alpha=0.05$ and the results point out that $\mathrm{H} 3$ is validated, hence the correlation is moderate by power $(r=0.32)$ which means that the tourists who are more likely inclined to recognize the destination as "my destination" have stronger confidence that they will come again for holiday in this destination. 
Table 3. Identification with the destination (statement "this is my destination")

\begin{tabular}{lcccc}
\hline Loyalty types & $\begin{array}{c}\text { Yes, } \\
\text { definitely } \\
(1)\end{array}$ & $\begin{array}{c}\text { Yes, to a } \\
\text { great extent } \\
(2)\end{array}$ & $\begin{array}{c}\text { Not really } \\
(3)\end{array}$ & Total \\
\hline $\begin{array}{l}\text { More than 15 recommendations } \\
\text { (cognitive loyalty) }\end{array}$ & $59.5 \%$ & $27.2 \%$ & $13.3 \%$ & $100.0 \%$ \\
$\begin{array}{l}\text { More than 3 visits at the resort for 8 year period } \\
\text { (behavioural loyalty) }\end{array}$ & $41.2 \%$ & $21.3 \%$ & $37.5 \%$ & $100.0 \%$ \\
\hline
\end{tabular}

Concerning the fourth hypothesis the research study reveals that: 1 . There is a relatively strong correlation between the 'cognitive' loyalty and the identification with the destination $(r=0.61)$; 2 . The correlation between the 'behavioural' loyalty and the tourists' identification with the destination is weaker than in the first case eg. moderate (coefficient $r=0.41$ ). Table 3 illustrates the results from cross tabulation between the variables related to cognitive and behavioural loyalty and the identification with the destination.

Concerning the fifth hypothesis the results from the regression analysis with 4 independent variables and dependent variable "decision for next visit" point out that there are some differences of the attributes' impact in seasons 2009 and 2010 (see Table 4) but the data reveal that the hypothesis was confirmed to a great extent. In addition to the destination attributes the impact of previous holidays/visits at the resort was examined in order to evaluate the personal experience impact on the decision for a next destination visit.
As seen from the table, the results for both seasons are similar but the impact of the positive experience is higher with the bigger sample in season 2010. This is not surprising for the author because in the experience economy which we are living now in consumers will base their brand loyalty according to Pine II and Gilmore (1999) not only on reliable service, but increasingly on the experience they will have with the brand. The detailed regression analysis allows the conclusion to be made that the impact of previous experience is higher on the decision for next visit taken by the tourist with 3 visits (moderate loyalty) and more than 3 visits (high loyalty level) (see Table 5).

Both samples reveal the same situation: the impact of the previous experience is lower on the decision for re-visiting the destination taken by the "beginners" and the tourists with 2 destination visits. Obviously it would be interesting to have a more representative sample because the findings can be generalized for the whole population.

Table 4. Destination attributes impact on the decision for next visit

\begin{tabular}{lcc}
\hline Destination attributes & season 2009 & season 2010 \\
\hline 1.Accommodation facilities & $\beta=0.30$ & $\beta=0.28$ \\
2.Safety and security & $\beta=0.21$ & $\beta=0.23$ \\
3. Clean and beautiful beaches & $\beta=0.20$ & $\beta=0.19$ \\
4. Positive previous experience & $\boldsymbol{\beta}=\mathbf{0 . 1 9}$ & $\boldsymbol{\beta}=\mathbf{0 . 2 5}$ \\
\hline
\end{tabular}

Table 5. Destination attributes impact on next visit decision in the different tourist clusters*

\begin{tabular}{lcccc}
\hline \multirow{3}{*}{ Destination attributes } & \multicolumn{2}{c}{ season 2009 } & \multicolumn{2}{c}{ season 2010 } \\
\cline { 2 - 5 } & $\begin{array}{c}3 \text { and more } \\
\text { visits }\end{array}$ & $\begin{array}{c}\text { 1 and 2 } \\
\text { visits }\end{array}$ & $\begin{array}{c}\text { 3 and more } \\
\text { visits }\end{array}$ & $\begin{array}{c}\text { 1 and } 2 \\
\text { visits }\end{array}$ \\
\hline 1.Accommodation facilities & $\beta=0.28$ & $\beta=0.27$ & $\beta=0.25$ & $\beta=0.30$ \\
2.Safety and security & $\beta=0.24$ & $\beta=0.23$ & $\beta=0.26$ & $\beta=0.25$ \\
3. Clean and beautiful beaches & $\beta=0.20$ & $\beta=0.22$ & $\beta=0.20$ & $\beta=0.24$ \\
4. Positive previous experience & $\boldsymbol{\beta}=\mathbf{0 . 2 1}$ & $\boldsymbol{\beta}=\mathbf{0 . 1 6}$ & $\boldsymbol{\beta}=\mathbf{0 . 2 4}$ & $\boldsymbol{\beta}=\mathbf{0 . 1 8}$ \\
\hline
\end{tabular}

${ }^{*} 1+2$ cluster $=3$ and more visits; $3+4$ cluster $=1$ and 2 visits 
Tourist loyalty and destination brand image perception: the case of Sunny beach resort, Bulgaria.

\section{Conclusions and destination marketing implications}

The findings from this study have some important marketing implications. Depending on the selected and implemented indicators for tourist loyalty identification a typology with 4 tourist segments was developed- 3 of them referring to three various loyalty levels: $1^{\text {st }}$ segment- tourists with high loyalty, $2^{\text {nd }}$ segment: tourists with moderate loyalty, $3^{\text {rd }}$ segment: prospective tourists in terms of loyalty and the segment of beginners: tourists who are for first time at the destination. Despite of the survey limitations this typology for tourists based on destination loyalty can be applied in all loyalty research in tourism despite of the destination type because the empirical indicators are not related to the tourism types.

The study data about the image perception by the tourists from the different clusters (high loyalty and moderate loyalty) provide useful indications for improving the destination image perception and the differentiation from other Black Sea resorts. Tourists with higher destination brand loyalty- the first identified cluster have clearer and more compact image perception than the tourists with moderate destination loyalty.

The study reveals that the previous positive experience is very important for the tourists when taking a decision about a destination visit. Having in mind that modern tourists in the experience economy are ready to pay for experience itself the destination marketers should consider that tourist experience becomes a key part of the destination product. As the study results point out that there are many complaints from the service quality in the third segment of the tourist typology, the management of Sunny Beach resort should develop and implement a programme for improvement of the tourists' experience, for example, to improve the perceived quality of the tourist services at the destination. Through appropriate marketing strategy the positive tourist experience can turn in brand experience and in one of the root causes underlying destination loyalty.
Other relevant finding of the content analysis of the image description is that cultural heritage around the resort is not perceived as an important attribute of Sunny Beach brand image. It would be helpful if Sunny Beach uses this resource in order to gain stronger and more unique brand image for its tourism product differentiation from other Black Sea resorts. The beautiful sandy beaches do not provide by themselves a competitive advantage for the destination and Sunny Beach resort needs to focus in its branding strategy on the "sightseeing opportunities and cultural heritage" in addition to the beautiful beaches. Both characteristics belong to the experience concept and if involved in the branding construct they could provide a unique and more attractive brand image.

As far as the tourist loyalty concern, the empirical evidence from the study confirms the findings from the previous study of the author in 2002 that the loyal tourists are "informal advocates" of Sunny Beach and can broadcast a clearer and more positive brand image of the destination and they should be stronger involved in the partnerships building for better destination marketing. The destination management body should establish a "Loyal tourist club" which can provide incentives for the loyal tourists- prizes, financial bonuses and intrinsic incentives like a title "Honourable tourist/client" of Sunny Beach resort. These tourists can easily become informal PR- staff for the destination.

Important relevant finding of the study is that one of the factors which impact the decision for a next destination visit is "safety and security" and the study results (Table 4) confirm the results as seen before from the study in Sunny Beach in 2002 and the survey in 2009 and reveal a growing impact of this factor for the tourists in the $21^{\text {st }}$ century - the era of terrorism, natural disasters and uncertainty. The conclusion is that destination marketing strategy of Sunny Beach should include brand messages that incorporate the feeling of safety and security. A future research with time series analysis can test the findings from these 2 customer surveys about the growing 
importance of the holiday value "safety and security of tourists".

As destination branding is a powerful tool for launching a favourable brand image to target segments, the destination marketers including those of Sunny Beach resort should monitor the brand image perceptions of the destination and identify the shifts in these perceptions which would be a good basis for improvement of the destination branding strategy based on exciting tourist experience.

\section{References}

Aaker, D. (1996). Building strong brands. New York: The Free Press.

Aaker, J., Fournier, S. and Brasel, S. A. (2004). When good brands do bad. Journal of Consumer Research, 31(1), 1-16.

Anastassova, L. (2004). The loyal tourist as an important partner for destination development and marketing. Petrillo, C. \& J. Swarbrooke (eds.). Proceedings of the ATLAS Annual Conference. Naples, Vol. 2, 415-424.

Anastassova, L., M. Jeleva \& Jelev, Y. (2010). New aspects in the training on safety and security in tourism. Paper presented at the Management and Sustainable Development Conference, 19-21.03.2010, Yudola, Bulgaria.

Anastassova, L. (2002). Loyalty to tourist destination: theoretical and practical aspects. Proceedings of the Conference "Tourism in the $21^{\text {st }}$ century", St.St. Kiril i Metodi, Sofia, pp.17-18

Arimond, G. and Elfessi, A. (2001). A clustering method for categorical data in tourism market segmentation research. Journal of Travel Research 39(4), 391-397.

Akama, J. S. \& Kieti, D. M. (2003) Measuring tourist satisfaction with Kenya's wildlife safari: a case study of Tsavo West National Park. Tourism Management, 24(1), 73-81

Baker, M. (1991). Research for marketing. Houndmills: MacMillan Education Itd.

Baker D. A. \& J. L. Crompton (2000). Quality, satisfaction and behavioral Intentions. Annals of Tourism Research, 27(3), 787-790.
Baloglu, S. \& McCleary, K. W. (1999). A model of destination image formation. Annals of Tourism Research, 26(4), 868-897.

Barich, H. \& Kotler, P. (1991). A framework for marketing image management. Sloan Management Review, 32(2), 94-104.

Bitner, M. J. (1995). Buiding relationships: It's all about promises. Journal of the Academy of Marketing Science, 23(4), 246-251.

Bitner, M. J. (1990). Evaluating service encounters: The effects of physical surroundings and employee responses. Journal of Marketing, 54(2), 69-82.

Blain, C., S. E. Levy \& J. R. Br. Ritchie (2005). Destination branding: insights and practices from destination management organizations. Journal of Travel Research, 43(4), 328-338.

Blattberg, R. C., G. Getz \& Thomas, J. S. (2009). Managing customer retention. Harvard Business Press.

Brodie, R., Coviello, N., Brookes, R. \& Little, V. (1997). Towards a paradigm shift in marketing? An examination of current marketing practices. Journal of Marketing Management, 13(5), 383406.

Buttle, F. (1996). Relationship marketing theory and practice. London: Chapman.

Cai, L. (2002). Cooperative branding for rural destinations. Annals of Tourism Research 29(3), 720-742.

Gallarza, M.G., Gil, I. \& Calderon, H. (2002). Destination image. Towards a conceptual framework. Annals of Tourism Research, 29(1), 56-78.

Chon, K. S. (1991). Tourism destination image modification process: marketing implications. Tourism Management, 12(1), 68-72.

Clark, I. D. (2009). Naming sites: Names as management tools in indigenous tourism sites - an Australian case study. Tourism Management, 30(1), 109-111.

Christopher, M., A. Payne \& Ballantyne, D. (2004). Relationship marketing. Oxford: Butterworth-Heinemann

Clifton, R. (2009). Brands and branding. $2^{\text {nd }}$ ed. The Economist Books 
Tourist loyalty and destination brand image perception: the case of Sunny beach resort, Bulgaria.

Crompton, J. L. (1979). An assessment of the image of Mexico as a vacation destination and the influence of geographical location upon the image. Journal of Travel Research 18(4), 1823.

Crompton, J. L. (1990). Attitude determinants in tourism destination choice. Annals of Tourism Research, 17(3), 432-448.

Day, J., Skidmore, S. \& Koller, T. (2002). Image selection in destination positioning: a new approach. Journal of Vacation Marketing, 8(2), 177-186.

De Wulf, K., Odekerken-Schroder G. \& Jaccobucci, D. (2001). Investments in consumer relationships: A crosscountry and cross-industry exploration. Journal of Marketing, 65(4), 33-50.

Dick, A. S. \& Basu, K. (1994). Customer loyalty: towards an integrated framework. Journal of the Academy of Marketing Science, 22(2), 99-100.

Echtner, C. \& R. J. B. Ritchie (1993). The measurement of destination image: an empirical assessment. Journal of Travel Research, 31(4), 5-13.

Flavian, C., Martinez, E. \& Polo, Y., (2001). Loyalty to grocery stores in the Spanish market of the 1990s. Journal of Retailing and Consumer Services, 8, 85-93.

Fornell, C. (1992). A national customer satisfaction barometer: the Swedish experience. Journal of Marketing, 56(Issue), 6-21.

Gartner, W. (1989). Tourism image: attribute measurement of state tourism products using multidimensional techniques. Journal of Travel Research, 28(2), 1620.

Gartner, W. (1993). Image formation process. Journal of Travel and Tourism Marketing, 2(2/3), 191-215.

Gilmore, J. (2002). The tourist crop. In: Gilmore, J. (ed.). Faces in the Caribbean. Monthly Review Press, London, Latin America Beaureu.

Govers, R., Go, F. M. \& Komar, K. (2007). Virtual destination image: A new measurement approach. Annals of Tourism Research, 34(4), 977-987.
Govers, R., Go, F. M. (2009). Place branding: glocal, virtual and physical identities, constructed, imagined and experienced. New York: Palgrave MacMillan.

Greenberg, M. (2008). Branding New York: How a city in crisis was sold to the world. New York: Routledge.

Groenroos, C. (1999). Relationship marketing: Challenges for the organization. Journal of Business Research, 46(3), 327-330.

Groeppel-Klein, A. Koenigstorfer, L. \& R. Terlutter A. (2008) .Verhaltenswissemschaftliche Aspekte der Kundenbindung. In: Bruhn M., Hamburg, C. (eds.). Handbuch Kundenbindungsmanagement. 6th ed., Wiesbaden, pp. 41-50

Gummesson, E. (1987). The new marketing developing long-term interactive relationships. Long-Range Planning, 20(4), 10-20.

Hall, C. M. \& Mitchell, R. T. (2002). Tourism as a force for gastronomic globalization and localization. In Hjalager, A. \& G. Richards (eds.). Tourism and gastronomy. London/New York: Routledge.

Howard, S. (1998). Corporate image management: A marketing discipline for the twenty-first century. Singapore: Butterworth-Heinemann Asia.

Huber, M. \& O'Gorman, S. (2010). From customer retention to a holistic stakeholder management system: Living a vision. Berlin: Springer Verlag.

Hunt, J. D. (1975). Image as a factor in tourism development. Journal of Travel Research, 13(3), 1-7.

Inbakaran, R. \& Jackson, M. (2006). Resident attitudes inside Victoria's tourism product regions: A cluster analysis. Journal of Hospitality and Tourism Management, 13(1), 59-74.

Ivanov, S. H., Illum, S. F. \& Liang, Y. (2010). Application of destination brand molecule on destination image and brand perception: An exploratory study. Tourism, 58(4), 339-360.

Iwasaki, Y. \& Havitz, M. E. (2004). Examining relationships between leisure 
involvement,

psychological

commitment and loyalty to a recreational agency. Journal of Leisure Research, 36(1), 45-72.

Jafari, J. (2000). Encyclopedia of tourism. Routledge World Reference, p. 85

Joppe, M., D. Martin \& J. Waalen (2001.) Toronto's Image as a destinaton: A comparative importance satisfaction analysis by origin. Journal of Travel Research, 39(3), 254-55.

Kapferer, J. N. (1992). Strategic brand management. New York: Free Press.

Keng, K. A. \& Cheng, J. L. (1999). Determining tourist role typologies: An exploratory study of Singapore vacationers. Journal of Travel Research, 37(4), 382390.

Khermouch, G., S. Holmes \& Moon Ihlwan (2001). The best global brands. Business Week (6 August).

Kim, S. S., McKercher, B. \& Lee, H. (2009). Tracking tourism destination image perception. Annals of Tourism Research, 36(4), 715-718.

Kohli, Ch. \& Leuthesser, L. (2001). Brand equity: Capitalizing on intellectual capital. Ivey Business Journal, 65(4), 74-81.

Konecnik, M. \& Gartner, W. (2007). Consumer based brand equity for a destination. Annals of Tourism Research, 34(2), 400-421.

Kotler, P. (1994). Marketing management: analysis, planning, implementation and control. Prentice Hall.

Kotler, P. (2010). Ingredient branding: making the invisible visible. Berlin: Springer Verlag.

Laws, E., Scott, N. \& Parfitt, N. (2002). Synergies in destination image management: a case study and conceptualisation. International Journal of Tourism Research, 4(1), 39-55.

Lewis-Cameron, A. \& Roberts, S. (eds.) (2010). Marketing islands destinations: concepts and cases. London: Elsevier.

Lin, C. T., \& Huang, Y. L. (2009). Mining tourist imagery to construct destination image position model. Expert Systems with Applications, 36(2), 2513-2524.
MacKay K. J. \& Fesenmaier, D. R. (1997). Pictorial element of destination in image formation. Annals of Tourism Research, 24(3), 537-565.

Marzano, G. \& Scott, N. (2009).. Power in destination branding. Annals of Tourism Research, 36(2), 247-267.

Mazanec, J. A. (1984). How to detect travel market segments: a clustering approach. Journal of Travel Research, 23(1), 17-21.

Michael, E. (2007). Micro-clusters and networks: the growth of tourism. Advances in Tourism Research Series. Elsevier Science

Morgan, N. \& Pritchard, A. (1999). Building destination brands. The case of Wales and Australia. Journal of Brand Management 7, 102-119.

Nadeau, J., Heslop, L., O’Reilly, N. \& Luk, P. (2008). Destination in a country image context. Annals of Tourism Research, 35(1), 84-106.

Niininen, O. \& Riley, M. (2003). Towards the conceptualization of tourism destination loyalty. Tourism Analysis, 8(2), 243246.

Oliver. R. L. (1997). Satisfaction. A behavioural perspective on the consumer. New York: Publisher?

Oliver, R. L. (1999). Whence consumer loyalty. Journal of Marketing, 63(Special issue 1999), 33-44.

Pike, S. (2004). Destination Marketing Organisations. Oxford: Elsevier.

Pine J. B. II \& G. H. Gilmore (1999). The experience economy: Work is theatre and every business a stage. Boston, MA: Harvard Business School Press.

Pride, R. (2004). A challenger brand: Wales, golf as it should be. In Morgan, N., A. Pritchard \& R. Pride (eds.). Destination branding: creating the unique destination proposition. Oxford: Butterworth \& Heinemann, pp. 159168.

Punj, G. \& Stewart, D. (1983). Cluster analysis in marketing research: review and suggestions for applications. Journal of Marketing Research, 20(2), 134-148.

Reichheld, F. F. (2001). The loyalty effect: the hidden force behind growth, profits and 
lasting value. Boston, MA: Harvard Business School Press.

Ritchie, J. R. \& J. R. B. Ritchie (1998). The branding of tourism destinations: past achievements and future challenges. Paper presented in the Annual Congress of the International Association of Scientific Experts in Tourism (AIEST), 1998, September, Marrakech, Morocco, pp. 22-23.

Travis, D. (2000). Emotional branding: how successful brands gain the irrational edge. Roseville, CA: Prima Venture.

Sheth, J. N. \& Parvatuyar, A. (eds.) (2000). Handbook of relationship marketing. Thousand Oaks: Sage.

Schmitt, B. \& A. Simonson (1997). Marketing aesthetics. The strategic management of brands, identity and image. Free Press.

Schultz, D. E. (1997). Relationship marketing: cutting both ways. Marketing news, 31, February $17^{\text {th }}$

Uhrich, B. (2008). Stadionsatmospaere als Verhaltenswissesnschaftliches

Konstrukt im Sportmarketing, Entwicklung und Validierung eines Messmodels. Wiesbaden: Gabler.
Uncles, M., G. Dowling \& Hammond, K. (2003). Customer loyalty and customer loyalty programmes. Journal of Consumer Marketing, 20(4), 294-300.

Wheeler, A. \& J. Katz (2011). Brand atlas: branding intelligence made visible. New Jersey: John Wiley and Sons.

Wheeler, A. (2009). Designing brand identity: an essential guide for the whole branding team. New Jersey: John Wiley and Sons.

White, C. J. (2004) Destination image: to see or not to see? International Journal of Contemporary Management, 16(5), 309-314.

Hospitality

Webb, J. R. (1992). Understanding and designing market research. London: Academic Press.

Yuksel, A. \& Akgul, O. (2007). Postcards as affective image makers: An idle agent in destination marketing. Tourism Management, 28(3), 714-725.

Yuksel, A., Yuksel, F. \& Bilim, Y. (2010). Destination attachment: effects on customer satisfaction and cognitive, affective and conative loyalty. Tourism Management, 31(2), 274-284. 


\title{
Appendix: Questionnaire
}

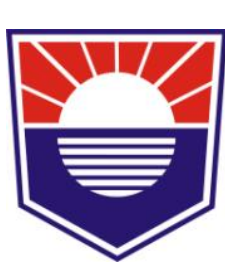

\author{
B O U R G A S F R E E \\ U N I V E R S I T Y \\ centerfor Business studies
}

\author{
QUESTION N AIRE
}

Dear guests,

The aim of this survey is to collect and analyze primary tourist data about the image perception of Sunny Beach by the tourists with different destination loyalty and to investigate the effect of satisfaction with the destination product attributes on their loyalty and the intention for next holiday at the destination. Some questions in the second part of the questionnaire concern also the hotel product and your tourist loyalty and satisfaction with its single attributes.

Please, read carefully and fill in the provided questionnaire before leaving the property for you travel back home!

Thank you very much for your assistance!

1. Which information channels did you use when choosing Sunny beach resort for your holiday?

\begin{tabular}{|l|c|}
\hline Information from friends, relatives, colleagues & 01 \\
\hline Information from Internet-sites of agencies and operators, social media & 02 \\
\hline Information from printed materials of tourist agencies and tour-operators & 03 \\
\hline Information from specialized journals and newspapers & 04 \\
\hline Information from TV and radio advertising & 05 \\
\hline Outdoor Advertising & 06 \\
\hline Other sources:....................................... & 07 \\
\hline
\end{tabular}

2. How was the decision for the holiday at Sunny beach taken (please point only the most appropriate answer)?

\begin{tabular}{|l|c|}
\hline Together with my partner (wife, husband) & 01 \\
\hline The most important is the opinion of the man in the family & 02 \\
\hline Normally most important is the opinion of the wife/woman & 03 \\
\hline Most important is the desire of the children & 04 \\
\hline The decision is taken only by myself & 05 \\
\hline
\end{tabular}

3. How many times have you been in this resort (for a period of 8 years)?

\begin{tabular}{|l|c|}
\hline This is my/our first holiday here & 01 \\
\hline For second time & 02 \\
\hline For third time & 03 \\
\hline More than 3 times & 04 \\
\hline
\end{tabular}


4. If you made some positive recommendations about Sunny Beach would you please state to how many people did you do this personally?

\begin{tabular}{|l|l|}
\hline Up to 5 persons & 01 \\
\hline From 5-9 persons & 02 \\
\hline From 10-15 persons & 03 \\
\hline To more than 15 persons & 04 \\
\hline I did not make any recommendations & 05 \\
\hline
\end{tabular}

5. To which extent do you agree that the following attributes are part of the established destination image of Sunny Beach?

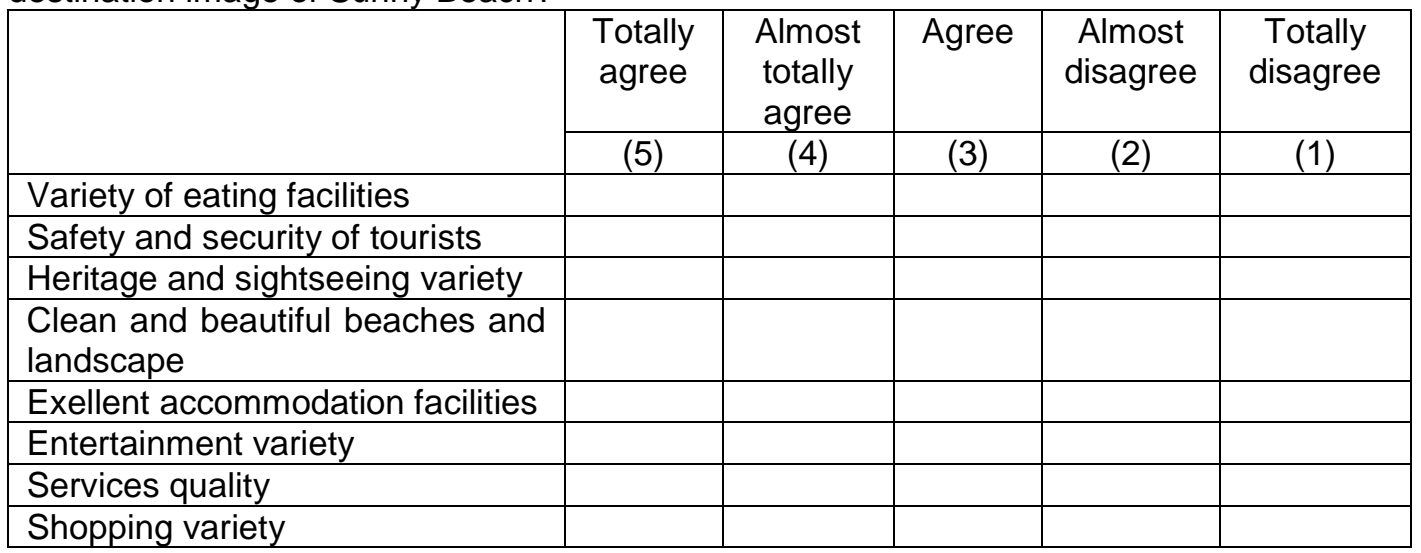

6. Can you say for Sunny Beach "This is my destination"?

\begin{tabular}{|l|c|}
\hline Yes, definitely & 01 \\
\hline Yes, almost sure & 02 \\
\hline To a great extent yes & 03 \\
\hline Probably not & 04 \\
\hline
\end{tabular}

7. Please fill in your opinion about the following statements (please give an answer on every row):

\begin{tabular}{|l|c|c|c|c|c|}
\hline & $\begin{array}{c}\text { Totally } \\
\text { agree }\end{array}$ & $\begin{array}{c}\text { Almost } \\
\text { totally } \\
\text { agree }\end{array}$ & Agree & $\begin{array}{c}\text { Almost } \\
\text { disagree }\end{array}$ & $\begin{array}{c}\text { Totally } \\
\text { disagree }\end{array}$ \\
\cline { 2 - 6 } & $(5)$ & $(4)$ & $(3)$ & $(2)$ & $(1)$ \\
\hline $\begin{array}{l}\text { The quality of services is } \\
\text { better than last year }\end{array}$ & & & & & \\
\hline $\begin{array}{l}\text { I will definitely recommend the } \\
\text { resort }\end{array}$ & & & & & \\
\hline I/we will come next year again & & & & & \\
\hline $\begin{array}{l}\text { I like more only the hotel } \\
\text { services }\end{array}$ & & & & & \\
\hline $\begin{array}{l}\text { I think the natural resources } \\
\text { are relatively preserved }\end{array}$ & & & & & \\
\hline $\begin{array}{l}\text { I consider Bulgaria as a good } \\
\text { destination for different kinds } \\
\text { of tourism }\end{array}$ & & & & & \\
\hline
\end{tabular}




\begin{tabular}{|l|l|l|l|l|l|}
\hline $\begin{array}{l}\text { I bought 1-3 excursions during } \\
\text { my holiday }\end{array}$ & & & & & \\
\hline $\begin{array}{l}\text { I bought 1-3 sport services } \\
\text { during my holiday }\end{array}$ & & & & & \\
\hline $\begin{array}{l}\text { I find the Bulgarian people } \\
\text { very hospitable }\end{array}$ & & & & & \\
\hline I met here a lot of new friends & & & & & \\
\hline $\begin{array}{l}\text { On my opinion generally the } \\
\text { tourism staff is highly qualified }\end{array}$ & & & & & \\
\hline $\begin{array}{l}\text { There is a specific own } \\
\text { atmosphere at the resort }\end{array}$ & & & & & \\
\hline $\begin{array}{l}\text { All Black Sea resorts are very } \\
\text { similar }\end{array}$ & & & & & \\
\hline $\begin{array}{l}\text { There are a lot of sightseeing } \\
\text { opportunities around }\end{array}$ & & & & & \\
\hline
\end{tabular}

8. How would you assess your satisfaction with the destination product attributes during your holiday? (5-exellent, 4- very good, 3- good, 2-satisfactory, 1-bad)

\begin{tabular}{|l|c|c|c|c|c|}
\hline & Excellent & $\begin{array}{c}\text { Very } \\
\text { good }\end{array}$ & Good & Satisfactory & $\begin{array}{c}\text { Unsatisfac } \\
\text { tory }\end{array}$ \\
\cline { 2 - 6 } & $(5)$ & $(4)$ & $(3)$ & $(2)$ & $(1)$ \\
\hline Accommodation facilities & & & & & \\
\hline $\begin{array}{l}\text { Safety and security of } \\
\text { tourists }\end{array}$ & & & & & \\
\hline $\begin{array}{l}\text { Heritage and sightseeing } \\
\text { variety }\end{array}$ & & & & & \\
\hline Beaches and landscape & & & & & \\
\hline Dining facilities & & & & & \\
\hline Entertainment variety & & & & & \\
\hline Services quality & & & & & \\
\hline Pleasant climate & & & & & \\
\hline Natural resources & & & & & \\
\hline $\begin{array}{l}\text { Shopping facilities and } \\
\text { communications }\end{array}$ & & & & & \\
\hline $\begin{array}{l}\text { Overall holiday } \\
\text { satisfaction }\end{array}$ & & & & & \\
\hline
\end{tabular}

9. If you compare your holiday experience with your previous expectations what is your opinion (please give an answer on every row):

\begin{tabular}{|l|c|c|c|c|}
\hline \multirow{2}{*}{$\begin{array}{l}\text { Holiday } \\
\text { Duration }\end{array}$} & $\begin{array}{l}\text { The experience } \\
\text { is worse than } \\
\text { the expectations }\end{array}$ & $\begin{array}{l}\text { There is almost } \\
\text { no difference } \\
\text { between both }\end{array}$ & $\begin{array}{l}\text { The experience } \\
\text { is better than } \\
\text { the expectations }\end{array}$ & $\begin{array}{l}\text { I did not have } \\
\text { any } \\
\text { expectations }\end{array}$ \\
\hline Under 5 days & $(1)$ & $(2)$ & $(3)$ & $(4)$ \\
\hline 1 week & & & & \\
\hline 10 days & & & & \\
\hline 2 weeks & & & & \\
\hline $\begin{array}{l}\text { More than } 2 \\
\text { weeks }\end{array}$ & & & & \\
\hline
\end{tabular}


10. Did you stay at the same hotel like the previous year?

\begin{tabular}{|l|l|}
\hline Yes, at the same hotel & 01 \\
\hline No, we were in a more expensive hotel & 02 \\
\hline No, we were in another hotel but from the same category & 03 \\
\hline No, we were in a cheaper hotel & 04 \\
\hline
\end{tabular}

11. How do you assess the hotel product attributes during your holiday?

\begin{tabular}{|l|c|c|c|c|}
\hline $\begin{array}{l}\text { Hotel product } \\
\text { Attributes }\end{array}$ & Excellent & Very good & Good & Not good \\
\hline & (5) & $(4)$ & $(3)$ & $(2)$ \\
\hline $\begin{array}{l}\text { Rooms: furniture and } \\
\text { comfortability }\end{array}$ & & & & \\
\hline Reception services & & & & \\
\hline Housekeeping services & & & & \\
\hline Restaurant- food and service & & & & \\
\hline Hotel animation services & & & & \\
\hline Hotel bar service & & & & \\
\hline General staff attitude to tourists & & & & \\
\hline
\end{tabular}

12. How much did you spend for excursions and sightseeing during your holiday?

\begin{tabular}{|l|c|c|c|c|}
\hline $\begin{array}{l}\text { Holiday } \\
\text { Duration }\end{array}$ & $\begin{array}{c}\text { Under } 50 \\
\text { Euro }\end{array}$ & $51-100$ Euro & $101-150$ Euro & $\begin{array}{c}\text { More than 150 } \\
\text { Euro }\end{array}$ \\
\hline Under 5 days & & & & \\
\hline 1 week & & & & \\
\hline 10 days & & & & \\
\hline 2 weeks & & & & \\
\hline More than 2 weeks & & & & \\
\hline
\end{tabular}

13. Overall impressions from the excursions organisation:

14. What do you think: Will you come again to this destination for holiday?

\begin{tabular}{|l|c|}
\hline Yes, definitely & 01 \\
\hline Almost sure & 02 \\
\hline To a great extent no & 03 \\
\hline Probably not & 04 \\
\hline
\end{tabular}

15. Could you share with us what didn't you like in Sunny Beach resort? 
16. Your family status:

\begin{tabular}{|l|l|}
\hline Married with children & 01 \\
\hline Married without children & 02 \\
\hline Not married/single & 03 \\
\hline Lives together with partner & 04 \\
\hline Divorced & 05 \\
\hline Widowed & 06 \\
\hline
\end{tabular}

17. Please describe your social status:

\begin{tabular}{|l|c|}
\hline Lower social level (including unemployed) & 01 \\
\hline Lower middle level & 02 \\
\hline Middle level & 03 \\
\hline Above middle social level & 04 \\
\hline
\end{tabular}

18. Your age group:

\begin{tabular}{|l|l|}
\hline From $18-25$ years & 01 \\
\hline $26-30$ years & 02 \\
\hline $31-39$ years & 03 \\
\hline $41-50$ years & 04 \\
\hline $51-60$ years & 05 \\
\hline $61-70$ years & 06 \\
\hline Over 70 years & 07 \\
\hline
\end{tabular}

Thank you very much!

Association test for 50 loyal tourists not included in the stratified sample ( 3 and more visits at the destination) and for $\mathbf{5 0}$ tourists with first or second visit):

Question:

Which are the 5 key words which come first to your mind when you hear the brand name "Sunny Beach": 